\title{
EVALUATION OF SELECTED PROPERTIES OF GLUTEN-FREE INSTANT GRUELS PROCESSED UNDER VARIOUS EXTRUSION-COOKING CONDITIONS*
}

\author{
Magdalena Kręcisz ${ }^{\bowtie}$, Agnieszka Wójtowicz \\ Department of Food Process Engineering, University of Life Sciences in Lublin \\ Doświadczalna 44, 20-280 Lublin, Poland
}

\begin{abstract}
Background. For consumers suffering with gluten intolerance, the only way to manage the condition is to avoid foods which are high in gluten. Instant gruels, processed from gluten-free corn and rice by extrusion cooking, could be used as a ready meal both for children and for adults on a gluten-free diet. The aim of the study was to evaluate the effects of various processing conditions on selected characteristics of corn-rice instant gruels.

Material and methods. Corn-rice mixtures (75:25 and 50:50) were processed at 12,14, 16 and 18\% of initial moisture content, using an extruder with screw speeds of 80, 100 and $120 \mathrm{rpm}$. Bulk density, water absorption and solubility, gel formation, color and sensory characteristics were assessed, under various processing conditions and with various corn:rice ratios.

Results. The composition of the raw materials, initial moisture content and screw speed applied during processing affected the characteristics of the corn-rice extruded instant gruels. Increasing the amount of rice in the recipe from 25 to $50 \%$ resulted in decreased bulk density, water solubility, volumetric gel formation ability and $b^{*}$ value. Increasing the initial moisture content increased the bulk density, $L^{*}, a^{*}$ and $b^{*}$ intensity, and gel formation index values of extrudates made with a 75:25 corn-rice recipe. Increased rpm increased extrudate solubility and water absorption, if the initial moisture content was higher than $14 \%$. The highest scores for overall acceptability were found for milk suspensions of 75:25 and 50:50 corn-rice instant gruels processed at 12 and $14 \%$ of initial moisture content, at $120 \mathrm{rpm}$.

Conclusion. Corn-rice instant gruels can be successfully produced by extrusion-cooking. Variable parameters, like the initial moisture content of raw materials or screw speed during processing significantly affected the properties of the products. An understanding of the effects of processing conditions on some qualities of extruded instant gruels allows more desirable products to be created. Moreover, the various components can be used for extruded products for consumers on gluten-free diets. Functional additives incorporated in the recipe to improve the nutritional value of the extrudates, which will be investigated in our upcoming research.
\end{abstract}

Keywords: extrusion-cooking, corn, rice, gluten-free

\footnotetext{
*This research was supported by a grant from the young scientists' TKP/MN/2 fund, by the Polish Ministry of Science and Higher Education.
} 


\section{INTRODUCTION}

Extrusion-cooking is one of the methods used for the production of grits and gruels for children. This technology is a process that involves the treatment of plant-based materials at high temperatures (up to $200^{\circ} \mathrm{C}$ ) and high pressures (up to $20 \mathrm{MPa}$ ), which causes significant changes in the physicochemical characteristics of the product and its qualities. Extrusion-cooking combines conveying, mixing, heating, shearing, cooking and forming into one device. The extrusion-cooking process is carried out in extruders, in which the main operative element is a screw or pair of screws fitted into a barrel (Mościcki et al., 2007). Food extrusion is a complex process because it requires continuous control of many different parameters to ensure that the products will have the desired characteristics and a balanced nutritional composition (Fleischman et al., 2016; Gbenyi et al., 2016; Mayachiew et al., 2015). Processing variables, i.e. screw speed, moisture content, temperature profile, raw material composition and feed rate, along with the die geometry and screw configuration, affect treatment intensity and parameters like residence time, as well as thermal and mechanical energy inputs (Choudhury and Gautam, 2003). Currently, extrusion-cooking technology is used in the food industry for the production of a wide variety of foodstuffs, including snacks, instant products, baby foods, breakfast cereals, texturized vegetable protein, pasta, crisp bread, etc. (Harper, 1981; Mościcki, 2013).

Corn (Zea mays L.) is one of the basic materials used in the production of extrusion-cooked foods and it is necessary to form a stable dough. Corn grit is obtained from dehulled and germ-free maize grains. The use of this as a raw material makes corn-based extruded products high in carbohydrates but low in protein, fat and fiber, and means that the final extrudates are of limited nutritional value (Gąsiorowski, 2006; Gondek et al., 2013). The nutritional value of extrudates produced from corn can be improved by using of different additives (Gondek et al., 2013; Oniszczuk et al., 2015; Ruiz-Ruiz et al., 2008; Zarzycki and Rzedzicki, 2009). In order to improve the physical and functional properties of extruded foods, several additives i.e. buckwheat, oat, rice or dry fruits and vegetables can be used (Bisharat et al. 2015; Ekielski et al., 2006; Mościcki, 2013; Stojceska et al., 2010; Wójtowicz et al., 2013).

Rice (Oryza sativa L.) is one of the most important plants for people in many countries. China, the world's largest producer of rice, produced 206.43 million tons in 2014 (National Bureau of Statistics of China, 2014). Rice is commonly used for the production of glutenfree foods due to its mild taste, hypoallergenic properties, white color and lightness, and high digestibility (which makes it suitable for children). In addition, other characteristics, like its low fat and protein content, mean that rice is preferred for people suffering from food allergies (Chuang and Yeh, 2004; Gujral and Rosell, 2004; Lawal et al., 2011; Torres and Fradinho, 2014). Rice possesses a unique nutritional composition, including many minerals (calcium, iron, magnesium, phosphorus, potassium, sodium, zinc, copper, manganese) and vitamins, especially of the $\mathrm{B}$ group $\left(\mathrm{B}_{1}, \mathrm{~B}_{6}\right)$ and vitamin $\mathrm{E}$ (Choudhury and Gautam, 2003; Domin et al., 2014).

These two aforementioned raw materials form the basis of a gluten-free diet, as they do not contain gluten. For consumers suffering from gluten intolerance, the only way to prevent allergic symptoms is to exclude all products made from wheat, barley or rye (Bouasla et al., 2016). Also, for children, glutenrich products should be incorporated into the diet after 4-6 months of age. There are several gluten-free products available on the market, including instant gruels for infants and children. Usually, instant gruels are processed by drum drying, and this energyintensive process means that these products are often expensive. Starch gelatinization and increased digestibility requires moistening, heating and then drying treated materials. A faster and cheaper alternative method for processing instant gruels from gluten-free raw materials could be extrusion-cooking (Kręcisz et al., 2015).

The aim of the study was to evaluate selected characteristics of gluten-free extruded instant gruels made from corn, with the addition of rice flour at a ratio of 75:25 and 50:50, processed under various conditions, i.e. by varying initial moisture content and screw rotational speed applied during the extrusion-cooking process. 


\section{MATERIAL AND METHODS}

As raw materials, corn grit (purchased from Lubella Sp. z o.o. Sp. k., Lublin, Poland) and rice flour (Rol-Ryż, Gdynia, Poland) were used. The chemical composition was determined according to AACC (2005) procedures: protein content (AACC 46-10), lipid content (AACC 30-10) and ash (AACC 08-01), in three replications. The AOAC (2000) procedure (AOAC 993.21) was carried out to determine the total dietary fiber. The proximate composition of $100 \mathrm{~g}$ of raw materials was as follows; for corn - protein: $9.24 \mathrm{~g}$, fat: $1.66 \mathrm{~g}$, ash: $0.50 \mathrm{~g}$, fiber: $7.2 \mathrm{~g}$, carbohydrates: $81.4 \mathrm{~g}$ (from difference), and for rice - protein: $8.28 \mathrm{~g}$, fat: $0.10 \mathrm{~g}$, ash: $0.50 \mathrm{~g}$, fiber: $3.97 \mathrm{~g}$, carbohydrates: $87.15 \mathrm{~g}$ (from difference).

\section{Sample preparation}

The raw materials, with a corn:rice ratio of 75:25 and 50:50, were mixed using a ribbon mixer and moistened with a specific volume of water (Wójtowicz, 2008) at $20^{\circ} \mathrm{C}$ to obtain the desired moisture content $(12,14,16$ and $18 \%$ ) before extrusion-cooking. The mixing time was set for 15 minutes to obtain a loose structure. The mixtures of raw materials were rested for 1 hour, to ensure an even moisture throughout the mixture. The moisture content of raw materials, moistened mixtures and extrudates were checked by drying (ASAE Standard, 1989) at $130^{\circ} \mathrm{C}$ for 1 hour, using an air dryer SWL-53 SDT (Pol-Eko-Aparatura, Wodzisław Śląski, Poland).

\section{Extrusion-cooking of instant gruels}

The corn-rice mixtures were processed using a singlescrew extruder TS-45 with L/D = 12:1 (ZMCh Metalchem, Gliwice, Poland). The temperature range at which the extrusion-cooking process took place was as follows: $125 / 130 / 135^{\circ} \mathrm{C}$ respectively, in three sections of the extruder. The process was carried out with rotational screw speeds of 80,100 and $120 \mathrm{rpm}$. A forming die, with a single opening of $3 \mathrm{~mm}$, was used. The extrudates were dried for 24 hours and ground with a laboratory grinder LMN10 (TestChem, Radlin, Poland) to a particle size below $1 \mathrm{~mm}$.

\section{Physical properties}

Bulk density was evaluated in five replications as a mass of specific sample volume using a measuring cylinder filled gently with corn-rice gruels (ASAE Standard, 1989). The bulk density of the samples was calculated from formula:

where:

$$
\rho_{b}=\frac{w_{s}}{V}, \mathrm{~kg} \cdot \mathrm{m}^{-3}
$$

$$
\begin{aligned}
& \rho_{b} \text { - bulk density, } \mathrm{kg} \cdot \mathrm{m}^{-3}, \\
& w_{s} \text { - weight of sample, } \mathrm{kg}, \\
& V \text { - volume, } \mathrm{m}^{3} .
\end{aligned}
$$

Water absorption index (WAI) was determined by centrifugation (Wójtowicz and Mościcki, 2014) for each sample in three replications. In brief, $0.7 \mathrm{~g}$ of extruded gruels was mixed with $7 \mathrm{~mL}$ of water for $10 \mathrm{~min}$ and then centrifuged at a rotational speed of $15000 \mathrm{rpm}$ for $10 \mathrm{~min}$ in a T24D-type centrifuge (MEDIZINETECHNIK, Leipzig, Germany). The supernatant was removed immediately, the remaining gel was weighed and the $W A I$ was calculated as:

where:

$$
W A I=\frac{w_{g}}{w_{s}}, \mathrm{~g} \cdot \mathrm{g}^{-1}
$$

$W A I$ - water absorption index, $\mathrm{g} \cdot \mathrm{g}^{-1}$,

$w_{g}$ - weight of gel, g,

$w_{s}-$ weight of dry sample, g.

Water solubility index (WSI) was determined, in triplicate, as solids recovered after total water evaporation at $110^{\circ} \mathrm{C}$ obtained from the $W A I$ analysis. Results were calculated with the formula:

where:

$$
W S I=\frac{w_{d s}}{w_{s}} \cdot 100, \%
$$

$W S I$ - water solubility index, \%,

$w_{d s}$ - weight of dry solids in supernatant, g,

$w_{s} \quad$ - weight of dry sample, g.

\section{Gel formation}

Volumetric gel index $(V G I)$ was determined according to the method developed by Kim et al. (2001), with our own modifications. $10 \mathrm{~mL}$ of the sample was suspended in $100 \mathrm{~mL}$ of distilled water at $20^{\circ} \mathrm{C}$ in a measuring cylinder, stirred over a $5 \mathrm{~min}$ period. The solution was allowed to swell for $20 \mathrm{~min}$ and then the gel volume was noted. The $V G I$ of the samples was calculated from the formula:

$$
W G I=\frac{V_{g}}{V_{t}} \cdot 100, \%
$$


where:

$V G I$ - volumetric gel index, \%,

$V_{g} \quad$ - volume of gel, $\mathrm{mL}$,

$V_{t} \quad$ - sample volume, $\mathrm{mL}$.

\section{Color parameters}

Color measurements were determined with a Lovibond CAM-System 500 colorimeter (the Tintometer, UK). CIE-Lab scale was used for evaluation of $L^{*}$ for lightness, $a^{*}$ for $(+)$ redness and $(-)$ greenness, and $b^{*}$ for $(+)$ yellowness and $(-)$ blueness, accordingly. Measurements were performed in 20 replications (Wójtowicz et al., 2013).

\section{Sensory analysis}

Sensory evaluations of the appearance, taste, color, mouth feel, stickiness and overall acceptability of instant gruels prepared with milk were performed. A semi-trained panel with 15 members (10 women, 5 men) evaluated products from each recipe on a 5-point scale. The panelists were given guidelines describing the requirements of each tested sensory attribute. Instant gruels were prepared with milk at room temperature in a 20:80 concentration, mixed continuously for 3 minutes to uniform consistency and served on the plates with appropriate codes. The samples were ordered randomly and tested. For the highest scores, appearance should be attractive and the color uniform and characteristic for the components used, taste should be pleasant and characteristic for components without any unusual taste or aftertaste, mouth feel should be smooth, creamy and homogenous without hard chunks, and stickiness should be delicate and regular and characteristic for a semi-solid meal. Each sample was given a score from 1 to 5 for each attribute, with 5 being the best possible score and 1 being the worst. Overall quality was defined as the mean value of all tested features (Wójtowicz et al., 2013).

\section{Statistical analysis}

The obtained results were tested with bidirectional ANOVA analysis of variance with interactions and Tukey's test for comparison of means $(p<0.05)$ was carried out with the Statistica software (Statistica version 10.0, USA). The first factor was the moisture content $(M C)$ and the second was the screw speed (SS). Response surface methodology $-R S M$ was used for fitting polynomial models $\left(Y=b_{0}+b_{1} X_{1}+b_{2} X_{2}+b_{11} X_{1}^{2}\right.$ $+b_{12} X_{1} X_{2}+b_{22} X_{2}^{2}$, where $X_{1}$ was the moisture content $M C$ and $X_{2}$ was the screw speed $S S$ applied) and quadratic equations of tested characteristics depended on variables used in the experiment (Table 1).

Table 1. Adequacy of two variables model fitted for tested characteristics of instant corn-rice gruels

\begin{tabular}{lcc}
\hline \multicolumn{1}{c}{ Parameters } & Fitted models & $R^{2}$ \\
\hline \multicolumn{1}{c}{ CR $75: 25$} & 2 & 4 \\
\hline$B D, \mathrm{~kg} \cdot \mathrm{m}^{-3}$ & $B D=-132.55+30.64 M C-0.074 S S+0.40 M C^{2}-0.14 M C S S+0.004 S S^{2}$ & 0.94 \\
$V G I, \%$ & $V G I=176.91-10.73 M C-1.12 S S+0.29 M C^{2}+0.04 M C S S+0.003 S S^{2}$ & 0.50 \\
$W A I, \mathrm{~g} \cdot \mathrm{g}^{-1}$ & $W A I=11.38-0.43 M C-0.05 S S-0.0004 M C^{2}+0.005 M C S S-7.9911 \mathrm{E}^{-5} S S^{2}$ & 0.49 \\
$W S I, \%$ & $W S I=58.96-6.02 M C+0.18 S S+0.18 M C^{2}-0.01 M C S S+0.0006 S S^{2}$ & 0.94 \\
$L^{*}$ & $L=64.09+2.14 M C-0.19 S S-0.06 M C^{2}+0.001 M C S S+0.001 S S^{2}$ & 0.80 \\
$a^{*}$ & $a=-0.12+0.15 M C-0.10 S S-0.03 M C^{2}+0.003 M C S S+0.0003 S S^{2}$ & 0.78 \\
$b^{*}$ & $b=-20.54-1.32 M C+1.20 S S+0.22 M C^{2}-0.03 M C S S-0.004 S S^{2}$ & 0,88 \\
$O a$ & $O a=-7.60+1.57 M C+0.01 S S-0.05 M C^{2}-0.003 M C S S+0.0002 S^{2}$ & 0.56 \\
\hline
\end{tabular}


Kręcisz, M., Wójtowicz, A. (2017). Evaluation of selected properties of gluten-free instant gruels processed under various extrusion-cooking conditions. Acta Sci. Pol. Technol. Aliment., 16(2), 135-147. http://dx.doi.org/10.17306/J.AFS.2017.0459

Table 1 cont

\begin{tabular}{llc}
\hline \multicolumn{1}{c}{1} & 2 & 4 \\
\hline \multicolumn{1}{c}{$\mathrm{CR} 50: 50$} & & \\
\hline$B D, \mathrm{~kg} \cdot \mathrm{m}^{-3}$ & $B D=-486.62+100.31 M C-2.20 S S-1.58 M C^{2}-0.29 M C S S+0.025 S S^{2}$ & 0.94 \\
$V G I, \%$ & $V G I=-197.83+19.01 M C+2.4 S S-0.52 M C^{2}-0.02 M C S S-0.012 S S^{2}$ & 0.75 \\
$W A I, \mathrm{~g} \cdot \mathrm{g}^{-1}$ & $W A I=7.41-0.03 M C-0.03 S S-0.01 M C^{2}+0.002 M C S S-2.3958 \mathrm{E}^{-5} S S 2$ & 0.42 \\
$W S I, \%$ & $W S I=85.76-5.47 M C-0.48 S S+0.12 M C^{2}+0.004 M C S S+0.002 S S^{2}$ & 0.75 \\
$L^{*}$ & $L=54.24+2.66 M C-0.054 S S-0.048 M C^{2}-0.009 M C S S+0.001 S S^{2}$ & 0.61 \\
$a^{*}$ & $a=-0.52-0.20 M C-0.06 S S+0.002 M C^{2}-0.0003 M C S S+0.0004 S S^{2}$ & 0.60 \\
$b^{*}$ & $b=20.42+0.48 M C+0.12 S S-0.003 M C^{2}+0.006 M C S S-0.001 S S^{2}$ & 0.77 \\
$O a$ & $O a=-7.23+1.58 M C+0.004 S S-0.05 M C^{2}-0.002 M C S S+0.0002 S^{2}$ & 0.61 \\
\hline
\end{tabular}

$M C$ - moisture content, $S S$ - screw speed, $B D$ - bulk density, $V G I$ - volumetric gel index, WAI - water absorption index, $W S I$ - water solubility index, $L^{*}$ - lightness, $a^{*}$ - redness/greenness balance, $b^{*}$ - yellowness/blueness balance, $O a$ - overall acceptability.

\section{RESULTS AND DISCUSSION}

The moisture content of instant gruels ranged from $6.27-8.47 \%$, both for $75: 25$ and 50:50 corn-rice contents in the recipe (data not shown). These levels of moisture content in extruded corn-rice gruels allow long-term storage and microbiological safety.

\section{Physical properties of corn-rice instant gruels}

The effect of processing variables on the bulk density of corn-rice instant gruels is presented in Figure 1. The influence of initial moisture content or raw materials on the bulk density values was significant (Table 2) and similar for both compositions: bulk density of the extrudates increased with the higher initial moisture content of raw materials with $R^{2}=0.84$ and 0.70 for 75:25 and 50:50 samples, respectively (Table 1). Low bulk density is preferred in infant and weaning foods (Gbenyi et al., 2016).

The same conclusions were made by Ding et al. (2006) for extruded wheat flour. For products based on the mixture of raw materials containing $25 \%$ rice, the bulk density ranged from $137.83 \mathrm{~kg} \cdot \mathrm{m}^{-3}$ to 362.18 $\mathrm{kg} \cdot \mathrm{m}^{-3}$ (Fig. 1a), while for mixtures with a corn-rice ratio of $50: 50$ it ranged from $150.63 \mathrm{~kg} \cdot \mathrm{m}^{-3}$ to 361.34 $\mathrm{kg} \cdot \mathrm{m}^{-3}$ (Fig. 1b). Products processed at low screw speed and with high initial moisture content were characterized by a more dense and less porous structure, which caused higher bulk density. Ruiz-Ruiz et al. (2008) reported that density values of extrudates from corn-bean mixtures varied from 237 to 436 $\mathrm{kg} \cdot \mathrm{m}^{-3}$, depending on extrusion temperature and moisture content, and concluded that density increased with increasing moisture content. A high screw speed when processing corn-rice mixtures moistened to $14 \%$ gives extrudates with a light weight, due to the porosity caused by intensive shearing inside the extruder. This behavior is characteristic for directly expanded snacks made from starchy raw materials, such as corn and rice (Hagenimana et al., 2006; Mościcki, 2013; Wójtowicz et al., 2012; Wójtowicz et al., 2013). Stojceska et al. (2010) reported bulk density of extrudates ranging from 100 up to $250 \mathrm{~kg} \cdot \mathrm{m}^{-3}$ for gluten-free extrudates and even up to $630 \mathrm{~kg} \cdot \mathrm{m}^{-3}$ if some fruit or vegetable fibers were added to the recipe. Gbenyi et al. (2016) reported a bulk density of extrudates from sorghum flour from 223 to $499 \mathrm{~kg} \cdot \mathrm{m}^{-3}$ if groundnut flour was addied. Fleischman et al. (2016) found a bulk density of $300 \mathrm{~kg} \cdot \mathrm{m}^{-3}$ for waxy wheat flour extrudates, which increased to up to $800 \mathrm{~kg} \cdot \mathrm{m}^{-3}$ if $37.5 \%$ of the mixture was replaced by wheat bran. Mayachiew et al. (2015) found that bulk density of extruded instant rice-soybean porridge ranged from 560 to $700 \mathrm{~kg} \cdot \mathrm{m}^{-3}$, and decreasing bulk density was observed as the proportion 
Kręcisz, M., Wójtowicz, A. (2017). Evaluation of selected properties of gluten-free instant gruels processed under various extrusion-cooking conditions. Acta Sci. Pol. Technol. Aliment., 16(2), 135-147. http://dx.doi.org/10.17306/J.AFS.2017.0459

Table 2. Analysis of variance and effect of variable processing parameters and its interactions on selected characteristics of corn-rice instant gruels

\begin{tabular}{|c|c|c|c|c|c|c|c|c|c|c|}
\hline $\begin{array}{l}\text { Source of } \\
\text { variation }\end{array}$ & $S S$ & $d f$ & $M S$ & $F$ & $p$ & $S S$ & $d f$ & $M S$ & $F$ & $p$ \\
\hline & \multicolumn{5}{|c|}{ CR 75:25 } & \multicolumn{5}{|c|}{ CR 50:50 } \\
\hline \multicolumn{11}{|c|}{$B D$} \\
\hline$M C$ & 252369.7 & 3 & 84123.2 & 1326.13 & 0.0000 & 163201.47 & 3 & 54400.49 & 842.30 & 0.0000 \\
\hline$S S$ & 28566.6 & 2 & 14283.3 & 225.15 & 0.0000 & 44218.07 & 2 & 22109.01 & 342.32 & 0.0000 \\
\hline$M C \times S S$ & 7450.7 & 6 & 1241.7 & 19.57 & 0.0000 & 13908.09 & 6 & 2318.05 & 35.89 & 0.0000 \\
\hline Error & 3044.98 & 48 & 63.43 & & & 3100.10 & 48 & 64.58 & & \\
\hline \multicolumn{11}{|c|}{ WAI } \\
\hline$M C$ & 0.37 & 3 & 0.12 & 3.71 & 0.0251 & 0.35 & 3 & 0.12 & 6.04 & 0.0032 \\
\hline$S S$ & 0.12 & 2 & 0.06 & 1.80 & 0.1855 & 0.19 & 2 & 0.09 & 4.91 & 0.0163 \\
\hline$M C \times S S$ & 1.31 & 6 & 0.21 & 6.58 & 0.0003 & 0.42 & 6 & 0.07 & 3.57 & 0.0114 \\
\hline Error & 0.79 & 24 & 0.03 & & & 0.47 & 24 & 0.02 & & \\
\hline \multicolumn{11}{|c|}{$W S I$} \\
\hline$M C$ & 688.29 & 3 & 229.43 & 436.12 & 0.0000 & 476.72 & 3 & 158.91 & 37.80 & 0.0000 \\
\hline SS & 86.65 & 2 & 43.19 & 82.12 & 0.0000 & 20.65 & 2 & 10.32 & 2.45 & 0.1070 \\
\hline$M C \times S S$ & 26.64 & 6 & 4.44 & 8.44 & 0.0001 & 60.05 & 6 & 10.01 & 2.38 & 0.0602 \\
\hline Error & 12.62 & 24 & 0.52 & & & 100.88 & 24 & 4.20 & & \\
\hline \multicolumn{11}{|c|}{$V G I$} \\
\hline$M C$ & 699.00 & 3 & 233.00 & 21.84 & 0.0000 & 878.75 & 3 & 292.92 & 24.40 & 0.0000 \\
\hline SS & 50.00 & 2 & 25.00 & 2.34 & 0.1175 & 564.50 & 2 & 282.25 & 23.52 & 0.0000 \\
\hline$M C \times S S$ & 438.00 & 6 & 73.00 & 6.84 & 0.0003 & 89.50 & 6 & 14.92 & 1.24 & 0.3199 \\
\hline Error & 256.00 & 24 & 10.67 & & & 288.00 & 24 & 12.00 & & \\
\hline \multicolumn{11}{|c|}{ Color profile $L^{*}$} \\
\hline$M C$ & 166.03 & 3 & 55.34 & 284.02 & 0.0000 & 68.04 & 3 & 22.68 & 84.14 & 0.0000 \\
\hline$S S$ & 12.94 & 2 & 6.47 & 33.20 & 0.0000 & 11.21 & 2 & 5.60 & 20.79 & 0.0000 \\
\hline$M C \times S S$ & 23.96 & 6 & 3.99 & 20.49 & 0.0000 & 25.42 & 6 & 4.23 & 15.72 & 0.0000 \\
\hline Error & 21.04 & 108 & 0.19 & & & 29.11 & 108 & 0.26 & & \\
\hline \multicolumn{11}{|c|}{ Color profile $a^{*}$} \\
\hline$M C$ & 63.32 & 3 & 21.11 & 168.98 & 0.0000 & 19.47 & 3 & 6.49 & 59.85 & 0.0000 \\
\hline$S S$ & 0.86 & 2 & 0.43 & 3.47 & 0.0346 & 2.40 & 2 & 1.20 & 11.07 & 0.0000 \\
\hline$M C \times S S$ & 2.94 & 6 & 0.49 & 3.93 & 0.0013 & 3.10 & 6 & 0.51 & 4.77 & 0.0002 \\
\hline Error & 13.49 & 108 & 0.12 & & & 11.71 & 108 & 0.108 & & \\
\hline \multicolumn{11}{|c|}{ Color profile $b^{*}$} \\
\hline$M C$ & 2248.73 & 3 & 749.58 & 661.96 & 0.0000 & 617.03 & 3 & 205.67 & 167.98 & 0.0000 \\
\hline$S S$ & 377.73 & 2 & 188.86 & 166.79 & 0.0000 & 129.59 & 2 & 64.79 & 52.92 & 0.0000 \\
\hline$M C \times S S$ & 408.03 & 6 & 68.00 & 60.05 & 0.0000 & 83.53 & 6 & 13.92 & 11.37 & 0.0000 \\
\hline Error & 122.29 & 108 & 1.13 & & & 132.23 & 108 & 1.22 & & \\
\hline \multicolumn{11}{|c|}{ Overall acceptability } \\
\hline$M C$ & 37.34 & 3 & 12.45 & 100.76 & 0.0000 & 43.12 & 3 & 14.37 & 115.89 & 0.0000 \\
\hline$S S$ & 1.74 & 2 & 0.87 & 7.03 & 0.0012 & 1.32 & 2 & 0.66 & 5.31 & 0.0058 \\
\hline$M C \times S S$ & 3.25 & 6 & 0.54 & 4.39 & 0.0004 & 2.80 & 6 & 0.47 & 3.76 & 0.0015 \\
\hline Error & 20.75 & 168 & 0.13 & & & 20.84 & 168 & 0.13 & & \\
\hline
\end{tabular}



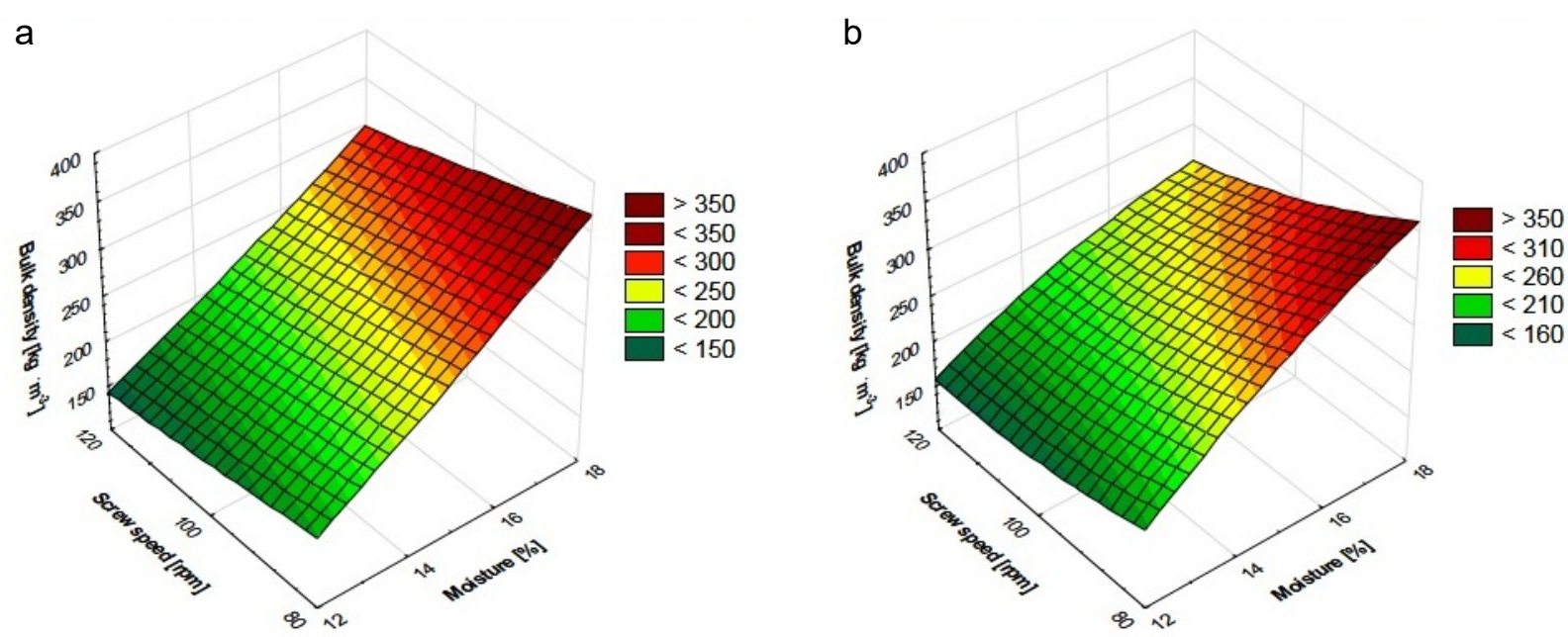

Fig. 1. Bulk density of corn-based instant gruels $(25 \%$ (a) and $50 \%$ (b) rice, depending on initial moisture content and screw speed applied during processing)

of legumes added to the mixture increased, up to $30 \%$ more than rice extruded porridge.

WAI indicates the amount of water absorbed by a gram of starch and is an indicator of extrusion-cooking intensity (Harper, 1981). The results of water absorption of instant corn-rice gruels ranged from 5.58 to $6.38 \mathrm{~g} \cdot \mathrm{g}^{-1}$ and were slightly higher for extrudates made from 50:50 corn-rice mixtures, while more differences were observed for the 75:25 corn-rice mixture. Extrudates made from both recipes, 25 and $50 \%$ rice, processed at the highest moisture level and at the lowest screw speed, as well as processed at the lowest moisture content and the highest screw speed, characterized low values of WAI, which suggest lower treatment intensity of starchy materials the under proposed conditions, and that the effect of screw speed on WAI may be insignificant (Table 2). For mixtures with $25 \%$ rice, processed at 80 and $100 \mathrm{rpm}$, an increase in initial moisture content lowered the WAI of extrudates. However, the application of $120 \mathrm{rpm}$ during processing increased $W A I$ of instant gruels as the initial moisture content of the raw materials increased (Fig. 2a). Similar tendencies were observed for 50:50 corn-rice extrudates (Fig. 2b). A lower water absorption capacity is desirable for making thinner gruels (Gbenyi et al., 2016). Results presented by Trela and Mościcki (2007) showed a similar tendency; increasing WAI if the amount of rice was increased in the recipe from 27 to $67.5 \%$, and if snack pellets were processed at $35 \%$

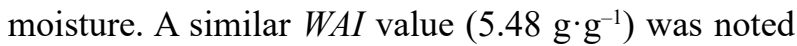
by Gondek et al. (2013) for corn-rice crisp bread processed using a twin-screw Clextral BC-45 extruder. Potato starch moistened to $18-30 \%$ and extruded with a single-screw extruder was characterized by similar properties: increasing moisture level of raw materials increased WAI of the extrudates (Mitrus et al., 2010). The WAI range reported by other authors depended on raw materials used, the type of extruder and processing conditions, and varied from 4.5 to $6.6 \mathrm{~g} \cdot \mathrm{g}^{-1}$ for gluten-free extrudates based on rice flour and from 3.6 to $5.6 \mathrm{~g} \cdot \mathrm{g}^{-1}$ for fiber-enriched extrudates (Stojceska et al., 2010) and from 5.3 to $6.2 \mathrm{~g} \cdot \mathrm{g}^{-1}$ for sorghum-bambara groundnut extrudates (Gbenyi et al., 2016). Similar results, varying from 5.6 to $6.4 \mathrm{~g} \cdot \mathrm{g}^{-1}$ were reported for $W A I$ of corn extrudates with added broccoli and olive paste (Bisharat et al., 2015), but a WAI almost 50\% lower was observed for extruded instant rice-soybean or rice-mung bean porridge, varying from 3.21 to 2.77 $\mathrm{g} \cdot \mathrm{g}^{-1}$, which decreased when the amount of legumes was increased (Mayachiew et al., 2015).

Water solubility index indicates the amount of unbounded components that leach out into the water after WAI measurements, but also can be an indicator of defragmentation of bounds responsible for the internal 
a

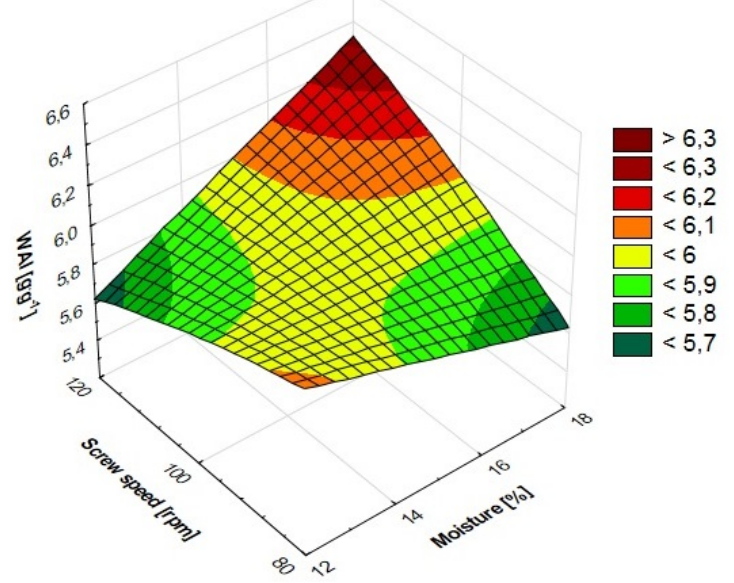

b

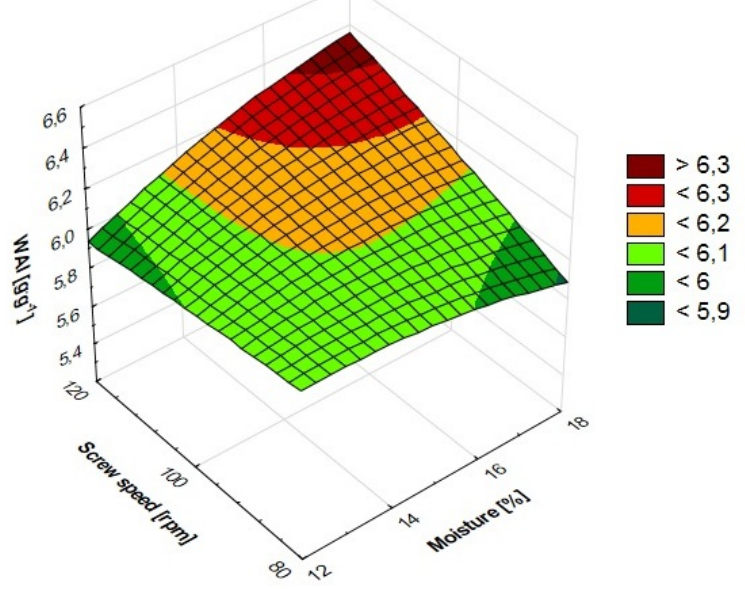

Fig. 2. Water absorption index (WAI) of corn-based instant gruels (25\% (a) and $50 \%$ (b) rice, depending on initial moisture content and screw speed applied during processing)

structure of the extrudates (Harper, 1981). WSI values of extruded instant gruels ranged from 7 to $24 \%$ for mixtures containing $25 \%$ rice, and from 8 to $18 \%$ for recipes based on 50:50 corn-rice mixtures. The WSI of corn-rice extruded crisp bread was $24.6 \%$, as reported by Gondek et al. (2013), or varied from 10.9 to $18.7 \%$ for corn extrudates with broccoli or olive paste added (Bisharat et al., 2015). Based on these results, it can be concluded that increasing moisture content of raw materials up to $18 \%$ resulted in a significant decrease in WSI values (Fig. 3) with $R^{2}=0.80$ and 0.71 for $75: 25$ and 50:50 recipes respectively. The low WSI values noted for extrudates processed with high moisture content showed good integration of components during treatment and low degradation of starchy components during thermo-mechanical treatment. Higher WSI was noted if raw materials with low moisture content were treated, because more intensive a

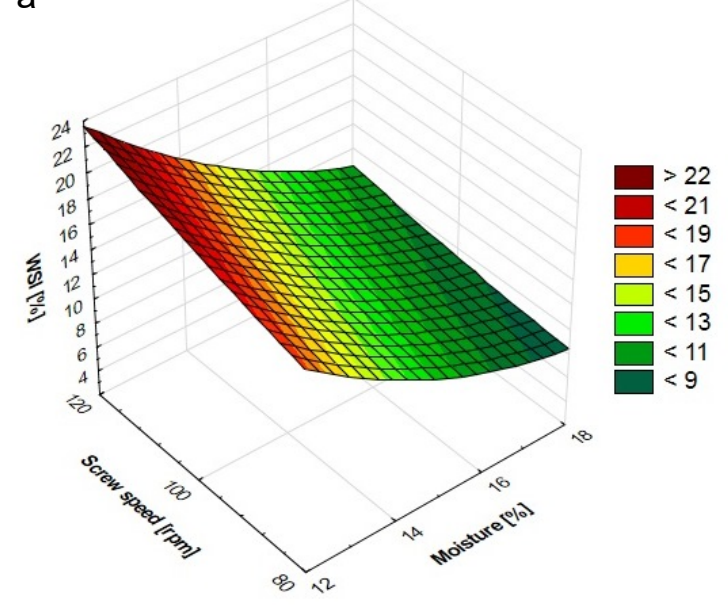

b

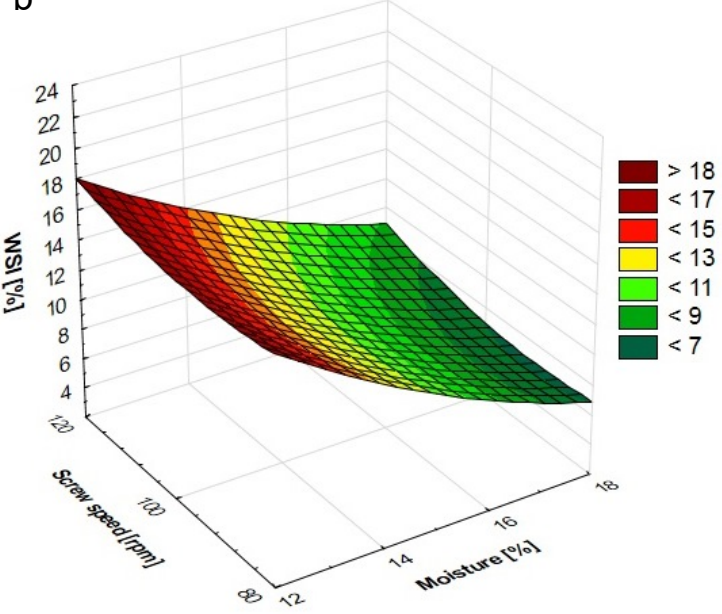

Fig. 3. Water solubility index (WSI) of corn-based instant gruels $(25 \%$ (a) and $50 \%$ (b) rice, depending on initial moisture content and screw speed applied during processing) 
a

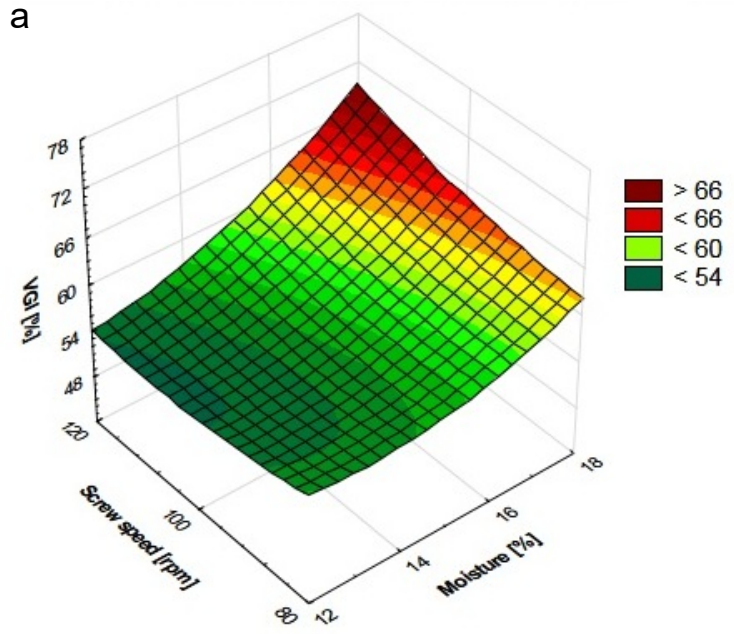

b

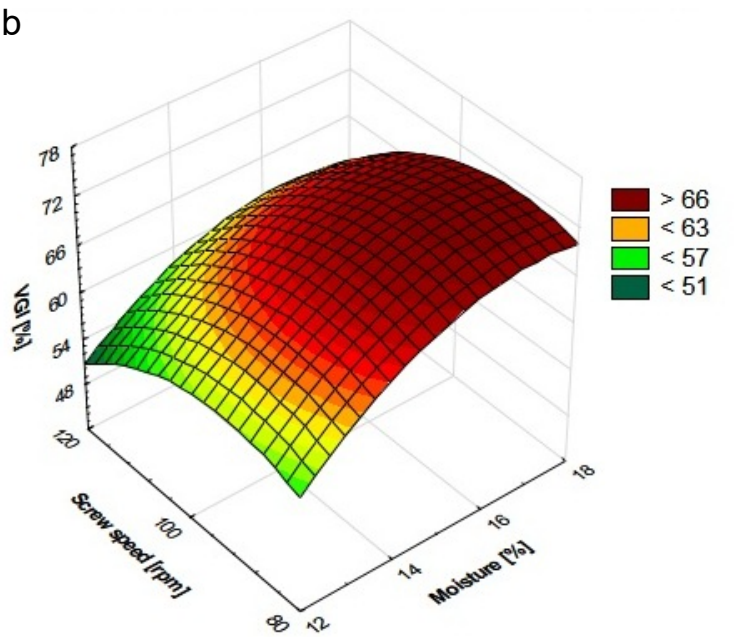

Fig. 4. Volumetric gel index (VGI) of corn-based instant gruels (25\% (a) and 50\% (b) rice, depending on initial moisture content and screw speed applied during processing)

treatment led to greater starch degradation in the final extrudates. A higher screw rpm applied during the extrusion-cooking of instant gruels increased WSI, but these trends were more intensive for 75:25 corn-rice extrudates (Fig. 3a). Similar observations were reported by Mitrus et al. (2010) for potato starch extrudates: increased WSI with higher rpm and decreased solubility with higher moisture level were noted. Increasing the proportion of buckwheat in mixtures with corn lowered the WSI of extrudates, as reported by Ekielski et al. (2006). WSI of extrudates processed with a twinscrew extruder from gluten-free raw materials ranged from 12.1 to $29.1 \%$ for extrudates enriched with fibers, because of higher treatment intensity in the twinscrew apparatus (Stojceska et al., 2010). Mayachiew et al. (2015) found that WSI ranged from 25.64 to $39.42 \%$ for rice-leguminous porridge extruded with a twin-screw extruder.

Volumetric gel index $(V G I)$ was tested to evaluate the ability of the instant gruels to form a stable consistency after water absorption. Kim et al. (2001) tested modified starches and its ability to form a gel when dissolved with water. Water absorption and gel formation are desirable for instant products served with water, milk or juice as ready-to-eat meals. The results presented in Figure 4 of the ability of instant gruels to form gels showed diverse extrudate behavior, processed with both raw material compositions in similar conditions. Instant gruels based on corn with $25 \%$ rice showed small differences in gel formation when moistened to 12 and $14 \%$, regardless of screw speed. (Table 2). A significant increase in $V G I$ was observed for these extrudates processed at 16 and $18 \%$ of initial moisture and at 100 and $120 \mathrm{rpm}$, which is supported by the WAI results. Different relationships were observed in the VGI results of 50:50 corn-rice instant gruels. The most intensive gel formation ability was observed for extrudates processed at 80 and $100 \mathrm{rpm}$ and $16-18 \%$ of initial moisture content. In these samples, application of the highest screw speed impeded the ability to form a volumetric structure of extrudatewater suspensions. It could be the result of a lower amount of water-soluble components, and all these components may be able to swell, absorb and keep water during hydration without further centrifugation.

\section{Color profile of instant gruels}

Color profile measurements of instant corn-rice gruels, according to the processing conditions and amount of rice added to the recipe, are presented in Table 3. In general, a more intensive lightness $L^{*}$, greenness $a^{*}$ and yellowness $b^{*}$ was observed as initial moisture content increased, and the significant impact of moisture content was observed both for 25 and $50 \%$ rice flour extrudates (Table 2), as $F$-values were lower. The screw speeds applied during processing have a lower 
Kręcisz, M., Wójtowicz, A. (2017). Evaluation of selected properties of gluten-free instant gruels processed under various extrusion-cooking conditions. Acta Sci. Pol. Technol. Aliment., 16(2), 135-147. http://dx.doi.org/10.17306/J.AFS.2017.0459

Table 3. Color coordinates of extruded corn-based instant gruels (25\% (a) and $50 \%$ (b) rice, depending on initial moisture content and screw speed applied during processing)

\begin{tabular}{|c|c|c|c|c|c|c|c|}
\hline \multirow{3}{*}{$\begin{array}{c}\text { Moisture } \\
\%\end{array}$} & \multirow{3}{*}{$\begin{array}{c}\text { Screw } \\
\text { speed } \\
\text { rpm }\end{array}$} & \multicolumn{4}{|c|}{ CR 75:25 } & \multicolumn{2}{|l|}{ CR 50:50 } \\
\hline & & \multicolumn{6}{|c|}{ color parameter } \\
\hline & & $L^{*}$ & $a^{*}$ & $b^{*}$ & $L^{*}$ & $a^{*}$ & $b^{*}$ \\
\hline \multirow[t]{3}{*}{12} & 80 & $73.14 \pm 0.43$ & $-5.58 \pm 0.41$ & $35.14 \pm 0.76$ & $72.50 \pm 0.44$ & $-5.74 \pm 0.34$ & $33.47 \pm 1.10$ \\
\hline & 100 & $72.98 \pm 0.41$ & $-5.66 \pm 0.39$ & $34.50 \pm 0.78$ & $73.14 \pm 0.60$ & $-5.74 \pm 0.34$ & $31.68 \pm 1.05$ \\
\hline & 120 & $73.46 \pm 0.39$ & $-5.50 \pm 0.42$ & $33.38 \pm 1.03$ & $74.90 \pm 0.60$ & $-5.02 \pm 0.25$ & $28.52 \pm 0.45$ \\
\hline \multirow[t]{3}{*}{14} & 80 & $74.10 \pm 0.60$ & $-5.50 \pm 0.42$ & $35.70 \pm 1.07$ & $74.02 \pm 0.41$ & $-5.74 \pm 0.34$ & $32.85 \pm 1.34$ \\
\hline & 100 & $74.62 \pm 0.50$ & $-5.82 \pm 0.25$ & $35.70 \pm 0.75$ & $73.94 \pm 0.47$ & $-5.82 \pm 0.25$ & $32.30 \pm 0.49$ \\
\hline & 120 & $75.62 \pm 0.37$ & $-5.90 \pm 0.00$ & $33.94 \pm 1.30$ & $73.98 \pm 0.50$ & $-5.98 \pm 0.25$ & $33.07 \pm 0.91$ \\
\hline \multirow[t]{3}{*}{16} & 80 & $75.78 \pm 0.45$ & $-6.84 \pm 0.35$ & $40.79 \pm 1.06$ & $75.66 \pm 0.48$ & $-6.30 \pm 0.42$ & $36.73 \pm 1.38$ \\
\hline & 100 & $75.94 \pm 0.51$ & $-6.94 \pm 0.39$ & $41.43 \pm 0.74$ & $74.74 \pm 0.54$ & $-6.38 \pm 0.41$ & $36.01 \pm 1.19$ \\
\hline & 120 & $75.30 \pm 0.57$ & $-6.54 \pm 0.34$ & $39.72 \pm 0.71$ & $75.66 \pm 0.69$ & $-6.06 \pm 0.34$ & $33.86 \pm 1.00$ \\
\hline \multirow[t]{3}{*}{18} & 80 & $76.14 \pm 0.30$ & $-7.64 \pm 0.30$ & $49.27 \pm 1.89$ & $75.10 \pm 0.54$ & $-6.78 \pm 0.25$ & $37.64 \pm 1.42$ \\
\hline & 100 & $75.40 \pm 0.37$ & $-7.34 \pm 0.34$ & $47.60 \pm 1.20$ & $74.98 \pm 0.32$ & $-6.62 \pm 0.25$ & $37.97 \pm 1.49$ \\
\hline & 120 & $77.45 \pm 0.30$ & $-7.02 \pm 0.41$ & $38.04 \pm 0.89$ & $75.06 \pm 0.54$ & $-6.30 \pm 0.42$ & $35.38 \pm 0.86$ \\
\hline
\end{tabular}

$L^{*}-$ lightness, $a^{*}(+)$ redness, $(-)$ greenness, $\mathrm{b}^{*}(+)$ yellowness, $(-)$ blueness; values are means of 20 replications \pm standard deviations.

impact on the color profile of tested samples. Color measurements showed lower or similar $L^{*}$ and $a^{*}$ values of corn-based instant gruels containing a higher proportion of rice (Table 3 ).

The $b^{*}$ values varied from 33.38 to 49.27 for extrudates with a $75: 25$ corn-rice ratio and from 28.52 to 37.97 for products made with a 50:50 corn-rice ratio. Color measurements showed lower $b^{*}$ values of extrudates made with more rice, because of the creamy-white color of rice flour. High yellowness was observed in all samples because of the presence of carotenoids in corn seeds and milled corn products.

\section{Sensory analysis}

The overall acceptability was expressed as the mean value of all the evaluated organoleptic properties. According to the results presented in Table 4, the best overall sensory profile score was for corn-rice instant gruels prepared with milk for extrudates processed with $14 \%$ of initial moisture content, at $120 \mathrm{rpm}$.
The scores for consistency were the most important for liquid or fluid semi-solid foods. It was noted that for mouth feel, as well as for stickiness, the highest scores were noted for instant meals prepared with milk on a base of $25: 75$ corn-rice gruels processed with 12 and $14 \%$ of initial moisture content at $120 \mathrm{rpm}$, as well as the 50:50 mixture extruded under similar conditions. The appearance and taste of instant gruels were given lower scores for extrudates processed with 16 and $18 \%$ moisture content at the highest screw speed, because of the presence of dense and insufficiently hydrated particles of extrudates affected by low water absorption and a weak ability to form a volumetric structure of extrudatewater suspensions. The results of the color evaluation confirmed the higher results for yellowness ( $b *$ profile) if 25:75 composition was tested. The most important variable affecting processing conditions was found to be moisture content, as indicated by high $F$ test values (Table 2). 
Kręcisz, M., Wójtowicz, A. (2017). Evaluation of selected properties of gluten-free instant gruels processed under various extrusion-cooking conditions. Acta Sci. Pol. Technol. Aliment., 16(2), 135-147. http://dx.doi.org/10.17306/J.AFS.2017.0459

Table 4. Sensory characteristic of extruded corn-based instant gruels (25\% (a) and $50 \%$ (b) rice, depending on processing conditions)

\begin{tabular}{|c|c|c|c|c|c|c|c|}
\hline \multirow{2}{*}{$\begin{array}{c}\text { Moisture } \\
\%\end{array}$} & \multirow{2}{*}{$\begin{array}{c}\text { Screw } \\
\text { speed } \\
\text { rpm }\end{array}$} & \multicolumn{6}{|c|}{ Sensory parameter } \\
\hline & & appearance ${ }^{*}$ & taste & colour $^{*}$ & mouth feel ${ }^{*}$ & stickiness $^{*}$ & $\begin{array}{c}\text { overall } \\
\text { acceptance }\end{array}$ \\
\hline \multicolumn{8}{|c|}{ CR 75:25 } \\
\hline \multirow[t]{3}{*}{12} & 80 & $3.40 \pm 0.80$ & $3.60 \pm 0.88$ & $4.00 \pm 0.36$ & $3.13 \pm 0.81$ & $3.60 \pm 0.71$ & 3.55 \\
\hline & 100 & $3.20 \pm 0.91$ & $3.47 \pm 0.88$ & $4.00 \pm 0.52$ & $3.67 \pm 0.60$ & $3.87 \pm 0.81$ & 3.64 \\
\hline & 120 & $4.27 \pm 0.68$ & $4.20 \pm 0.54$ & $4.27 \pm 0.57$ & $4.13 \pm 0.62$ & $4.13 \pm 0.34$ & 4.20 \\
\hline \multirow[t]{3}{*}{14} & 80 & $3.53 \pm 1.16$ & $4.04 \pm 1.06$ & $3.99 \pm 0.96$ & $3.63 \pm 1.00$ & $3.85 \pm 1.22$ & 4.00 \\
\hline & 100 & $3.92 \pm 0.94$ & $3.95 \pm 1.02$ & $3.82 \pm 0.89$ & $4.10 \pm 0.99$ & $3.95 \pm 0.99$ & 4.15 \\
\hline & 120 & $4.33 \pm 0.70$ & $4.20 \pm 0.75$ & $4.33 \pm 0.60$ & $4.40 \pm 0.61$ & $4.40 \pm 0.71$ & 4.33 \\
\hline \multirow[t]{3}{*}{16} & 80 & $3.07 \pm 0.85$ & $3.67 \pm 0.79$ & $3.93 \pm 0.57$ & $3.33 \pm 0.78$ & $3.40 \pm 0.95$ & 3.48 \\
\hline & 100 & $3.33 \pm 0.87$ & $3.33 \pm 0.87$ & $4.00 \pm 0.63$ & $3.20 \pm 0.91$ & $2.73 \pm 0.99$ & 3.32 \\
\hline & 120 & $3.13 \pm 0.88$ & $2.67 \pm 1.01$ & $4.13 \pm 0.49$ & $3.27 \pm 0.92$ & $3.27 \pm 0.68$ & 3.29 \\
\hline \multirow[t]{4}{*}{18} & 80 & $2.70 \pm 1.00$ & $2.51 \pm 1.06$ & $3.45 \pm 0.96$ & $2.84 \pm 0.82$ & $2.41 \pm 0.89$ & 2.88 \\
\hline & 100 & $2.86 \pm 0.86$ & $2.62 \pm 0.92$ & $3.67 \pm 0.92$ & $2.69 \pm 1.17$ & $2.37 \pm 0.94$ & 2.97 \\
\hline & 120 & $2.69 \pm 0.93$ & $2.80 \pm 0.96$ & $3.68 \pm 1.06$ & $2.70 \pm 0.82$ & $2.43 \pm 0.87$ & 2.99 \\
\hline & & & & CR 50:50 & & & \\
\hline \multirow[t]{3}{*}{12} & 80 & $3.47 \pm 0.71$ & $3.67 \pm 0.94$ & $3.87 \pm 0.49$ & $2.93 \pm 0.68$ & $3.67 \pm 0.70$ & 3.52 \\
\hline & 100 & $3.13 \pm 0.96$ & $3.40 \pm 0.88$ & $3.93 \pm 0.57$ & $3.53 \pm 0.62$ & $3.87 \pm 0.62$ & 3.57 \\
\hline & 120 & $4.20 \pm 0.75$ & $4.13 \pm 0.62$ & $4.13 \pm 0.72$ & $4.13 \pm 0.72$ & $4.00 \pm 0.52$ & 4.12 \\
\hline \multirow[t]{3}{*}{14} & 80 & $3.64 \pm 1.20$ & $3.93 \pm 1.04$ & $3.93 \pm 0.96$ & $3.58 \pm 0.98$ & $3.74 \pm 1.27$ & 3.95 \\
\hline & 100 & $3.87 \pm 0.96$ & $3.88 \pm 0.98$ & $3.76 \pm 0.90$ & $3.97 \pm 1.00$ & $3.65 \pm 1.01$ & 4.01 \\
\hline & 120 & $4.20 \pm 0.75$ & $4.07 \pm 0.77$ & $4.20 \pm 0.65$ & $4.20 \pm 0.83$ & $4.20 \pm 0.91$ & 4.17 \\
\hline \multirow[t]{3}{*}{16} & 80 & $3.00 \pm 0.82$ & $3.53 \pm 0.85$ & $3.87 \pm 0.62$ & $3.20 \pm 0.83$ & $3.20 \pm 1.11$ & 3.36 \\
\hline & 100 & $3.27 \pm 0.85$ & $3.27 \pm 0.85$ & $3.93 \pm 0.68$ & $3.20 \pm 0.91$ & $2.67 \pm 0.94$ & 3.27 \\
\hline & 120 & $2.93 \pm 0.99$ & $2.53 \pm 0.96$ & $4.07 \pm 0.57$ & $3.20 \pm 0.91$ & $3.13 \pm 0.72$ & 3.17 \\
\hline \multirow[t]{3}{*}{18} & 80 & $2.47 \pm 1.00$ & $2.32 \pm 1.05$ & $3.39 \pm 0.93$ & $2.71 \pm 0.78$ & $2.11 \pm 0.69$ & 2.68 \\
\hline & 100 & $2.79 \pm 0.81$ & $2.32 \pm 0.91$ & $3.55 \pm 1.01$ & $2.56 \pm 1.13$ & $2.00 \pm 0.74$ & 2.76 \\
\hline & 120 & $2.45 \pm 0.95$ & $2.60 \pm 1.00$ & $3.62 \pm 1.05$ & $2.51 \pm 0.85$ & $2.28 \pm 0.72$ & 2.81 \\
\hline
\end{tabular}

${ }^{*} 5$-point scale.

${ }^{* *}$ Mean value; values are means of 15 replications \pm standard deviations. 


\section{CONCLUSIONS}

The initial moisture content of raw materials and the screw speed applied during processing had significant effects on most tested properties of corn-rice instant gruels. A higher level of moisture in the raw materials increased bulk density, $L^{*}, a^{*}$ and $b^{*}$ intensity, and $V G I$ values of extrudates made with 75:25 corn-rice mixture. Increasing initial moisture content to $18 \%$ in corn-rice extrudates caused higher bulk density and $V G I$ but lower WSI values. A higher rpm applied during processing resulted in increased WSI and WAI of the instant gruels, especially if the initial moisture content was more than $14 \%$. Increasing screw speed from 80 to $100 \mathrm{rpm}$ increased the ability of 50:50 corn-rice extrudates to form a gel, but higher rpm decreased $V G I$ for these samples. Increasing rice content in the recipe from 25 to $50 \%$ resulted in decreased bulk density, WSI, VGI and $b^{*}$ value. Nevertheless, both 75:25 and 50:50 corn-rice recipes can be used as raw materials for processing gluten-free instant gruels by extrusion-cooking.

\section{REFERENCES}

AACC (1995). Approved methods of the American Association of Cereal Chemists (9th ed.). USA: St. Paul.

AOAC (2000). Official methods of AOAC International (17th ed.). Gaithersburg, MD, USA: AOAC International.

ASAE Standard. (1989). ASAE S269.3. Wafers, pellet, and crumbles - definitions and methods for determining density, durability and moisture content.

Bisharat, G., Katsavou, I., Panagiotou, N., Krokida, M., Maroulis, Z. (2015). Investigation of functional properties and color chan ges of corn extrudates enriched with broccoli or olive paste. Food Sci. Techn. Int., 21(8), 613-630. http://dx.doi.org/10.1177/1082013214559310

Bouasla, A., Wójtowicz, A., Zidoune, M. N., Olech, M., Nowak, R., Mitrus, M., Oniszczuk, A. (2016). Gluten-free precooked rice-yellow pea pasta: effect of extrusion-cooking conditions on phenolic acids composition, selected properties and microstructure. J. Food Sci., 81, 5, C1070-1079. http://dx.doi. org/10.1111/1750-3841.13287

Chuang, G. C.-C., Yeh, A. I. (2004). Effect of screw profile on residence time distribution and starch gelatinization of rice flour during single screw extrusion cooking.
J. Food Eng., 63, 21-31. http://dx.doi.org/10.1016/ S0260-8774(03)00278-4

Choudhury, G., Gautam, A. (2003). Effects of hydrolysed fish muscle on intermediate process variables during twin-screw extrusion of rice flour. Lebensm.-Wiss. u. Technol., 36, 667-678. http://dx.doi.org/10.1016/ S0023-6438(03)00087-2

Ding, Q.-B., Ainsworth, P., Plunkett, A., Tucker, G., Marson, H. (2006). The effect of extrusion conditions on the functional and physical properties of wheat-based expanded snacks. J. Food Eng., 73, 142-148. http://dx.doi. org/10.1016/j.jfoodeng.2005.01.013

Domin, M., Kluza, F., Góral, D., Kozłowicz, K., Nakonieczny, P. (2014). Ocena stopnia skleikowania skrobi ziaren ryżu powodowanego ich gotowaniem, zamrażaniem i zamrażalniczym przechowywaniem [Assessment of rice starch gelatinization caused by boiling, freezing and frozen storage of rice grains]. Acta Sci. Pol., Technica Agraria, 13(3-4), 3-13 [in Polish].

Ekielski, A., Majewski, Z., Żelaziński, T. (2006). Wpływ dodatku gryki na własności ekstrudatu kukurydzianego [The influence of buckwheat supplement on the properties of maize extrudate]. Inż. Roln., 7, 82, 155-161 [in Polish].

Fleischman, E., Kowalski, R., Morris, C., Niguyen, T., Li, C., Ganjyal, G., Ross, C. (2016). Physical, textural, and antioxidant properties of extruded waxy wheat flour snack supplemented with several varieties of bran. J. Food Sci., 81, 11, E2726-E2733. http://dx.doi. org/10.1111/1750-3841.13511

Gąsiorowski, H. (2006). Kukurydza. Część 9. Metoda ekstruzji [Corn. Part 9. Extrusion method]. Przegl. Zboż.-Młyn. 9, 51-52 [in Polish].

Gbenyi, D., Nkama, I., Badau, M. H. (2016). Optimization of physical and functional properties of sorghum-bambara groundnut extrudates. J. Food Res., 5, 2, 81-97. http://dx.doi.org/10.5539/jfr.v5n2p81

Gondek, E., Jakubczyk, E., Wieczorek, B. (2013). Właściwości fizyczne bezglutenowego pieczywa chrupkiego [Physical properties of gluten-free crisp bread]. Zesz. Probl. Post. Nauk Roln., 574, 29-38 [in Polish].

Gujral, H. S., Rosell, C. M., (2004). Functionality of rice flour modified with a microbial transglutaminase. J. Cereal Sci., 39, 225-230. http://dx.doi.org/10.1016/j. jcs.2003.10.004

Hagenimana, A., Ding, X., Fang, T. (2006). Evaluation of rice flour modified by extrusion cooking. J. Cereal Sci., 43, 38-46. http://dx.doi.org/10.1016/j.jcs.2005.09.003

Harper, J. M. (1981). Extrusion of foods. Boca Raton, USA: CRC Press. 
Kręcisz, M., Wójtowicz, A. (2017). Evaluation of selected properties of gluten-free instant gruels processed under various extrusion-cooking conditions. Acta Sci. Pol. Technol. Aliment., 16(2), 135-147. http://dx.doi.org/10.17306/J.AFS.2017.0459

Kim, Y., Faqih, M. N., Wang, S. S. (2001). Factors affecting gel formation of inulin. Carbohyd. Polym., 46, 135-145.

Kręcisz, M., Wójtowicz, A., Oniszczuk, A. (2015). Produkcja ekstrudowanych odżywek dla dzieci [Production of extruded foods for children]. Zesz. Probl. Post. Nauk Roln., 582, 13-21 [in Polish].

Lawal, O.S., Lapasin, R., Bellich, B., Olayiwola, T. O., Cesàro, A., Yoshimura, M., Nishinari, K. (2011). Rheology and functional properties of starches isolated from five improved rice varieties from West Africa. Food Hydrocoloid., 25, 7, 1785-1792. http://dx.doi. org/10.1016/j.foodhyd.2011.04.010

Mayachiew, P., Charunuch, C., Devahastin, S. (2015). Physicochemical and thermal properties of extruded instant functional rice porridge power as affected by the addition of soybean or mung bean. J. Food Sci., 80, 12, E2782E2791. http://dx.doi.org/10.1111/1750-3841.13118

Mitrus, M., Wójtowicz, A., Mościcki, L. (2010). Modyfikacja skrobi ziemniaczanej metodą ekstruzji [Potato starch modification by extrusion-cooking technique]. Acta Agroph., 16 (1), 101-109 [in Polish].

Mościcki, L., Mitrus, M., Wójtowicz, A. (2007). Technika ekstruzji w przemyśle rolno-spożywczym [Extrusion-cooking technique in agri-food industry]. Warszawa: PWRiL [in Polish].

Mościcki, L. (2013). Ekstruzja w przetwórstwie rolno-spożywczym. Cz. II. Surowce stosowane w produkcji wyrobów ekstrudowanych [Extrusion-cooking in agri-food processing. P. II. Raw materials in extrudates production]. Przegl. Zboż.-Młyn. 2, 6-8 [in Polish].

National Bureau of Statistics of China (2015). Retrieved February 26, 2015, from http://www.stats.gov.cn/english/ (28.04.2016).

Oniszczuk, A., Wójtowicz, A., Oniszczuk, T., Olech, M., Nowak, R., Wojtunik, K., ..., Hajnos, M. (2015). Extruded corn groats containing linden flowers: quantitation of phenolic compounds and selected quality characteristics. Open Chem., 13, 1209-1217. http://dx.doi. org/10.1515/chem-2015-0138

Ryu, G. H., Ng, P. K. (2001). Effect of selected process parameters on expansion and mechanical properties of wheat flour and whole cornmeal extrudates. Starch/Stärke, 53, 147-154. http://dx.doi.org/10.1002/1521-379X(200 104)53:3/4<147::AID-STAR147>3.0.CO;2-V

Ruiz-Ruiz, J., Martínez-Ayala, A., Drago, S., González, R., Betancur-Ancona, D., Chel-Guerrero, L. (2008).
Extrusion of a hard-to-cook bean (Phaseolus vulgaris L.) and quality protein maize (Zea mays L.) flour blend. LWT - Food Sci. Technol., 41(10), 1799-1807. http:// dx.doi.org/10.1016/j.lwt.2008.01.005

Stojceska, V., Ainsworth, P., Plunkett, A., İbanoğlu, S. (2010). The advantage of using extrusion processing for increasing dietary fibre level in gluten-free products. Food Chem., 121(1), 156-164. http://dx.doi. org/10.1016/j.foodchem.2009.12.024

Torres, M. D., Fradinho, P. (2014). Thermorheological and textural behaviour of gluten-free gels obtained from chestnut and rice flours. Food Bioproc. Technol., 7, 11711182. http://dx.doi.org/10.1007/s11947-013-1132-6

Trela A., Mościcki L. (2007). Wpływ procesu ekstruzji na wybrane cechy jakościowe peletów zbożowych [Influence of extrusion proces on selected quality properties of cereal pellets]. Żywn. Nauka Techn. Jakość, 5(54), 43-54 [in Polish].

Wójtowicz, A. (2008). Wpływ nawilżania surowców oraz parametrów procesu ekstruzji na wybrane cechy zbożowych kaszek błyskawicznych [Influence of raw materials wetting and extrusion-cooking process conditions on selected properties of instant cereal grits]. Acta Agroph., 11(2), 545-556 [in Polish].

Wójtowicz, A., Pasterniak, E., Juśko, S., Hodara, K., Kozłowicz, K. (2012). Wybrane cechy jakościowe chrupek kukurydzianych $\mathrm{z}$ dodatkiem odtłuszczonych nasion lnu. Acta Sci. Pol., Technica Agraria, 11, 3-4, 25-33 [in Polish].

Wójtowicz, A., Kolasa, A., Mościcki, L. (2013). The influence of buckwheat addition on physical properties, texture and sensory characteristic of extruded corn snacks. Polish J. Food Nutr. Sci., 63, 4, 239-244. http://dx.doi. org/10.2478/v10222-012-0076-2

Wójtowicz, A., Mościcki, M. (2014). Influence of legume type and addition level on quality characteristics, texture and microstructure of enriched precooked pasta. LWT - Food Sci. Technol., 59, 1175-1185. http://dx.doi. org/10.1016/j.lwt.2014.06.010

Zarzycki, P., Rzedzicki, Z. (2009). Wpływ dodatku komponentów wysokobiałkowych na właściwości fizyczne ekstrudatów kukurydziano-owsianych [Effect of high protein components on physical properties of corn-oat extrudates]. Acta Agroph., 13, 1, 281-291 [in Polish]. 